\title{
"Supra-stewardship": a tool for citizen participation in European Union pandemic preparedness planning
}

\author{
MARK L FLEAR*
}

Queen's University Belfast

\begin{abstract}
$\underline{\text { Abstract }}$
This article proposes developing the public bioethics aspect of stewardship and applying it to the European Union (EU) as "supra-stewardship", a tool for opening a discursive space for citizen participation in EU pandemic preparedness planning. With this in mind, the article highlights some of the contours for engagement on the boundaries of responsibility and production of governance distortions and failures brought out by attention to framing, distribution, vulnerability and learning. This should belp citizens to tackle the complementary expert and public rationalities that undermine their involvement, contribute supplementary knowledge towards governance, and help promote institutional learning by the EU and resilience.
\end{abstract}

Key words: pandemic influenza; preparedness; security; participation; supra-stewardship

\section{Introduction}

7 he EU has an increasingly prominent role in public health issues, ${ }^{1}$ as highlighted by its 1 pandemic preparedness planning, such as for the recent influenza strain H1N1 or "swine flu". 2 This planning aims to ensure the EU is of "added value" in the face of "emergency"3 by respecting member state (MS) responsibility for the "management of health services and medical care and the allocation of the resources assigned to them". 4 It does so by ensuring the interoperability of proliferating MS plans and, as an instance of reflexive governance or the "government of governments", 5 the readiness of "essential

* Lecturer in Law, School of Law, Queen's University Belfast (m.flear@qub.ac.uk). The support of the British Academy (SG-48186 EU Governance of AIDS, Cancer and Obesity: Governmentality, Citizenship and Polity), the ESRC (PI: RES-451-26-0764 European Law and New Health Technologies) and UACES (PI: A Symposium with Professor Roger Brownsword: Super-stewardship in the Context of Public Health) are acknowledged with gratitude. Thanks to Roger Brownsword, Tammy Hervey, Jean McHale, John Morison, Thérèse Murphy, Dieter Pesendorfer, Sara Ramshaw, Anastasia Vakulenko, Sally Wheeler and the peer reviewer. The usual disclaimer applies.

1 For an overview, see T K Hervey and J V McHale, Health Law and the European Union (Cambridge: CUP 2004).

2 For instance, www.bbc.co.uk/health/physical_health/conditions/swineflumulti1.shtml (last accessed 5 September 2011).

3 As required by the principle of subsidiarity in Article 5(1) and (3) amended Treaty on European Union (TEU).

4 Article 168(7) Treaty on the Functioning of the European Union (TFEU) (emphasis added).

5 Coining Dean's “government of government”: M Dean, Governmentality 2nd edn (London: Sage 2010), p. 226. 
infrastructures". These comprise: planning and coordination; monitoring and assessment; prevention and containment; health system response; and communication. EU preparedness distributes responsibilities ${ }^{6}$ around the EU's multi-level system of governance to a range of actors, including: the European Commission (the Commission); the European Centre for Disease Control (ECDC); MS authorities; private actors such as manufacturers of vaccines; the news media; and the EU's citizenry. ${ }^{7}$ While the "imperative of preparedness is not new", 8 EU preparedness (hereafter simply preparedness) is still quite a recent and underexplored phenomenon. ${ }^{9}$

Working within science and technology studies' (STS) view that "the technical is political", Jasanoff terms risk assessment and management techniques like preparedness "technologies of hubris" since they make problems like pandemics visible in an effort to manage them and keep the economy working. ${ }^{10}$ Making a point that resonates with the governmentality perspective used in this article and introduced in section 2 below, Jasanoff stresses how these technologies operate to depoliticise and naturalise governance, and as such help to quiet contestation and dissent, and ultimately legitimate that governance. Yet, they also engender "perils of prediction", especially in contexts of high uncertainty, such as masking the normative in the technical, and the production of governance distortions and failures.

Jasanoff asserts that identifying, managing and potentially correcting such "perils" requires a "civic epistemology" that gathers supplementary knowledge from throughout society. ${ }^{11}$ This is to be achieved through a "technology of humility": citizen participation around the focal points of framing, vulnerability, distribution and learning to query the purpose of risk governance, whom it hurts, whom it benefits, and how we might know. ${ }^{12}$ Given this, how might citizen participation around the focal points be facilitated to resist depoliticisation and naturalisation of governance, to raise awareness and promote discussion around the boundaries of responsibility as well as the production of governance distortions and failures, and generate knowledge for decision-making? How might law specifically human rights ${ }^{13}$ - assist in facilitating this task and with what tools?

While recognising that citizen participation requires a range of formal and informal mechanisms, processes and fora, I focus on constructing a biopolitical ${ }^{14}$ discursive space in which citizens can use the focal points to demand and contest decision-making. I develop and seek to facilitate human rights' recent interest in citizen participation - also a hot topic in the

6 S J Collier and A Lakoff, "Distributed preparedness: space, security and citizenship in the United States" (2008) 26(1) Environment and Planning, D: Society and Space 7.

7 Article 9 TEU and Article 20 TFEU.

8 F Lentzos and N Rose, "Governing insecurity: contingency planning, protection, resilience" (2009) 38(2) Economy and Society 230, pp. 235-6.

9 Cf. S Mounier-Jack and R Coker, "Pandemic influenza: are Europe's institutions prepared?” (2006) 16(2) European Journal of Public Health 119; S L Greer, "The European Centre for Disease Prevention and Control: hub or hollow core?" and H Elliott, S L Greer and D K Jones, "Mapping disease control in the European Union", (2011) Journal of Health Politics, Policy and Law (forthcoming).

10 S Jasanoff, "Technologies of humility: citizen participation in governing science" (2003) 41 Minerva 223, p. 238.

11 Ibid; S Jasanoff, Designs on Nature (Woodstock: Princeton UP 2005), p. 250.

12 Jasanoff, "Technologies of humility", n. 10 above.

13 After the "human rights revolution" law tends to be thought of "as a system of rights which frames and contains government power": N Walker, "Review of M Loughlin, Sword and Scales: An examination of the relationship between law and politics" (2001) Public Law 644, p. 646 (emphasis added).

14 Jasanoff, Designs on Nature, n. 11 above, p. 36. See also: M Dillon and L Lobo-Guerrero, "Biopolitics of security in the 21st century" (2008) 34(2) Review of International Studies 265. 
$\mathrm{EU}^{15}$ - as being about empowerment. ${ }^{16}$ Attention to empowerment resonates with the nuance in STS that "the technical is potentially political", 17 in that it helps attune framing, vulnerability, distribution and learning towards the identification of disempowerment and potentially unjust power relations - that is, when citizen participation makes sense and preparedness should be political. ${ }^{18}$

This is part of a broader attempt by human rights to develop something other than a zero-sum relationship with discourses of risk, safety and security, ${ }^{19}$ and maintain a connection with the targets of governance especially in fast-moving contexts typified by high uncertainty. Human rights must also demonstrate efficacy in the face of competition for regulatory relevance - and different figurations of citizen participation - from the other points of the "bioethical triangle" shaping governance: a largely restrictive and disempowering dignitarian perspective ${ }^{20}$ and a pragmatic utilitarian perspective. Even as failure might create a "toxic" backlash against human rights as it seeks to shape risk governance, encouraging public interest has been highlighted as the main benefit of such an approach. ${ }^{21}$ At the same time, citizen participation around the focal points is intended to recognise the possibility of ambiguity or unforeseen consequences, supplement dominant technologies of hubris, and as such might make governance and human rights more resilient in the event of failure.

Bearing in mind Moore's observation that "public bioethics has so far remained largely separate from the analysis of public participation in scientific governance", 22 in the next section I nominate and seek to instrumentalise the public bioethics aspect of stewardship, a model for population-level bioethics that is linked to and inflected by human rights. As I explain, this link to human rights makes stewardship adept at being honed into suprastewardship by and for citizens: a tool to open a discursive space around, and their participation in, preparedness.

In section 3, I suggest how supra-stewardship could be used to make an initial attempt at bringing out the normative in the technical by exploring the construction of preparedness through discourses of risk, security, public understanding of science (PUS), and which are undergirded by neoliberalism. I recommend only some of the contours for engagement on the boundaries of responsibility and governance distortions and failures brought out by attention to framing, distribution and vulnerability. Further, I highlight the denial of citizens' potential to connect with and make a substantive contribution towards

15 Making it a site of great hope for the democratisation of the global governance of life: S Jasanoff, "Biotechnology and empire: the global power of seeds and science" (2006) 21 OSIRIS 273.

16 M Flear and A Vakulenko, "A human rights perspective on citizen participation in the EU's governance of new technologies” (2010) (10)4 Human Rights Law Review 661.

17 A Moore, "Beyond participation: opening up political theory in STS" (2010) 40(5) Social Studies of Science 793, p. 797 (emphasis added). This is a review of: M B Brown, Science in Democracy: Expertise, institutions and representation (Cambridge MA: MIT Press 2009).

18 Brown, Science in Democracy, ibid. Also see: A E Yamin, "Suffering and powerlessness: the significance of promoting participation in rights-based approaches to health" (2009) 11 Health and Human Rights 5.

19 Such as "rights as risk" and "risk within rights" in: T Murphy and N Whitty, "Is human rights prepared? Risk, rights and public health emergencies" (2009) 17 Medical Law Review 219.

20 For example, see: R Brownsword, "Human dignity, ethical pluralism, and the regulation of modern biotechnologies" in T Murphy (ed.), New Technologies and Human Rights (Oxford: OUP 2009).

21 T Murphy, "Technology, tools and toxic expectations: post-publication notes on New Technologies and Human Rights" (2009) 2 Law, Innovation and Technology 181.

22 A Moore, "Public bioethics and public engagement: the politics of "proper talk" (2010) 19(2) Public Understanding of Science 197, at p. 197. Also: A Moore, "Public bioethics and deliberative democracy" (2010) 58 Political Studies 715. 
governance through their construction within a disempowering "deficit model" as being in need of education through their participation. ${ }^{23}$ This "peril of prediction" complements the hubristic expert rationality in preparedness. In the final section, I explain that suprastewardship might help citizens to resist the deficit model, especially by allowing them to contribute knowledge towards decision-making, and promote institutional learning by the EU as well as resilience.

\section{Supra-stewardship}

In sketching supra-stewardship I overview and highlight some key and useful features of stewardship models in the context of public health. I do not examine their respective advantages and disadvantages. ${ }^{24} \mathrm{I}$ use a critical theory and especially Foucault-influenced way of thinking about supra-stewardship, citizen participation and governance. Put simply, I am interested in these as discourses because they literally produce power - and provide a way to shape it. ${ }^{25}$ In the context of disease, epidemiology and risk have historically laid the basis for governance. Their focus on population as the "end and instrument of government", make it "possible to think, reflect, and calculate . . . outside the juridical framework of sovereignty", 26 and give rise to governmentality.

In this setting freedom is "one of the facets . . of the deployment of apparatuses of security". ${ }^{27}$ Security is about responding "to a reality in such a way that . . [it] cancels out the reality to which it responds... regulates it". ${ }^{28}$ In late modernity there is resort to neoliberal rationality ${ }^{29}$ through the use of market techniques and practices of "governing at a distance" in order to induce self-management and optimisation of health and welfare. 30 Extending this are moves towards reflexive governance. Dean explains that these work by "securing the mechanisms of government. Society itself can be changed, according to this view . . . through transformation of the mechanisms by which it had previously been governed". ${ }^{31}$ Moreover, the accountability and legitimacy of governmentality becomes ever more important as formally accountable sites of power tighten their relations with science and technology, 32 and citizens engage with this reflexively as a "knowledge society". 33

23 Flear and Vakulenko, "A human rights perspective", n. 16 above.

24 Cf. the other articles in this special issue. This article uses the approach and borrows elements developed elsewhere: Flear and Vakulenko, "A human rights perspective", n. 16 above.

25 M Foucault, The History of Sexuality, vol. I: The will to knowledge (London: Penguin 1998), p. 101.

26 M Foucault, Security, Territory, Population: Lectures at the Collège de France, 1977-1978 (Basingstoke: Palgrave Macmillan 2007), pp. 104-5.

27 Ibid. p. 49.

28 Ibid. p. 47.

29 Rose et al. describe "rationality" as "a way of doing things that ... [is] oriented to specific objectives and that ... [reflects] on itself in characteristic ways": N Rose, P O’Malley and M Valverde, "Governmentality" (2006) 2 Annual Review of Law Society and Science 83, p. 84.

30 M Foucault, The Birth of Biopolitics: Lectures at the Collège de France, 1978-1979 (Basingstoke: Palgrave Macmillan 2008). Cf. T Lemke, “'The birth of biopolitics': Michel Foucault's lecture at the Collège de France on neoliberal governmentality" (2001) 30(2) Economy and Society 190; W Brown, Edgework. (Woodstock: Princeton UP 2005), pp. 39-44.

31 Dean, Governmentality, n. 5 above, p. 226 (emphasis added).

32 W Brown, Regulating Aversion: Tolerance in the age of identity and empire (Princeton NJ: Princeton UP 2006), p. 15; Jasanoff, Designs on Nature, n. 11 above, pp. 5-6.

33 D Bell, The Coming of Post-Industrial Society: A venture in social forecasting (Harmondsworth: Basic Books 1976); M Castells, The Rise of the Network Society (=The Information Age, vol. I) (Oxford: Blackwell 1996); K Knorr Cetina, Epistemic Cultures. How the sciences make knowledge (Cambridge MA: Harvard UP 1999); N Stehr, Knowledge Societies (London: Sage 1994). 
In light of this, supra-stewardship can be sketched out. In the World Health Organisation's (WHO) version, stewardship is linked and even conflated with governance. ${ }^{34}$ The World Health Report 2000 explains how stewardship essentially involves "setting and enforcing the rules of the game and providing strategic direction for all the different actors involved". 35 It is "the very essence of good government", with state governments having the "[u]ltimate" 36 responsibility.

More recently, the Nuffield Council on Bioethics in its report Public Health: Ethical issues $^{37}$ (Nuffield) sought to develop a human rights-based approach to incorporate a precautionary way of thinking into population-level bioethics for public health contexts. Three of Nuffield's authors, Baldwin, Brownsword and Schmidt, note how stewardship means that "liberal states have responsibilities to look after important needs of people both individually and collectively. Therefore, states are stewards both to individual people ... and to the population as a whole". 38 Developing stewardship beyond the state into "superstewardship" is noted by Brownsword as "a significant item of unfinished business". 39

Part of that task is developing the public bioethics aspect of stewardship as a tool for citizen participation. As Ashcroft explains, public bioethics is "a set of practices for legitimating the "social license to practise" 40 of medicine and the broader governance of life. Recognising the de-legitimating crises and failures of late modernity's technologies of hubris - such as bovine spongiform encephalopathy (BSE) and genetically modified organisms (GMOs) - and in an attempt to tackle normative concerns, there has been a widespread turn towards bioethics - including within the EU - that arguably displaces the centrality of those scientific and technical models. ${ }^{41}$ As such, instrumentalising and widening the rhetorical opening provided by public bioethics is a useful resource for a human rights-oriented and inspired perspective interested in empowering citizens.

I use the term supra-stewardship to emphasise the EU's sui generis or supra-national nature and focus on the public bioethics aspect of its stewardship responsibilities towards its citizens. $^{42}$ In adopting a human rights-oriented approach, I suggest only some of the contours for empowerment of citizens as they bring out the normative in technical through engagement around the boundaries of responsibility and the production of governance distortions and failures. This engagement is facilitated by attention to framing, distribution, vulnerability and learning. I stop short of establishing criteria for assessing preparedness or prescribing the precise features of supra-stewardship. In an empowering way, it is for

34 "Stewardship and governance": www.euro.who.int/en/what-we-do/health-topics/Health-systems/ stewardship-and-governance (last accessed 5 September 2011).

35 "Message from the Director General, Gro Harlem Brundtland" in WHO, World Health Report 2000 (Geneva: WHO 2000), p. viii.

36 Ibid. Also see: WHO, World Health Day: International health security: invest in health, build a safer future (Geneva: WHO 2007).

37 Nuffield Council on Bioethics, Public Health: Ethical issues (London: Nuffield Council on Bioethics 2007).

38 T Baldwin, R Brownsword and H Schmidt, "Stewardship, paternalism and public health: further thoughts" 2(1) Public Health Ethics (2009) 113, p. 115 (emphasis added). Citing Nuffield Council, Public Health, n. 37 above, p. 25.

39 R Brownsword, "So what does the world need now? Reflections on regulating technologies" in R Brownsword and K Yeung (eds), Regulating Technologies: Legal futures, regulatory frames and technological fixes (Oxford: Hart 2008), p. 47.

40 R Ashcroft, "Could human rights supersede bioethics?” (2010) 10(4) Human Rights Law Review 639, p. 645.

41 Moore, "Public bioethics and public engagement: the politics of "proper talk", n. 22 above.

42 Cf. S Holm, "From steward to Stuart: some problems in deciding for others" and T Hervey, "The European Union, its Court of Justice and 'super-stewardship' in public health" (containing an extensive review of the EU's deeply contested nature), both developing the EU's stewardship role in this special issue. 
citizens to explore further the protean, open-textured and polyvalent nature of stewardship so that they might hone a tool for their participation in governance.

As an indication, in terms of framing, when informed by the WHO, supra-stewardship could ensure a focus on "improving overall levels of population health" 43 and "Oversight of the entire system, avoiding myopia, tunnel vision and the turning of a blind eye to a system's failings". ${ }^{44}$ References to pandemic planning in the WHO and Nuffield versions of stewardship do emphasise essential infrastructures, but they are part of a broader attention to population and the conditions that support it. Importantly, Nuffield uses pandemic influenza as a jumping-off point for considering cross-border obligations, noting how it is "also reasonable" to apply stewardship at a "much higher level". 45 The central example given - duplicated by the EU and noted as problematic below - is that countries should notify others of a serious infectious disease outbreak, following WHO procedures. Yet, since such cross-border obligations require an efficient surveillance system and some countries lack such capabilities, richer countries become obligated to "seek to enhance the capacities of developing countries to conduct effective surveillance of infectious diseases". ${ }^{46}$ Surveillance is "not simply a national matter". ${ }^{47}$ Interestingly, the ECDC is referred to here, alongside the WHO and the Centers for Disease Prevention and Control in the United States, as "international partners". 48

As elaborated below, a focus on pandemics in cross-border governance has implications for distribution and vulnerability, both within the EU and in its external relations, and they could be teased out by stressing wider public health objectives. For instance, similar to Nuffield, the WHO notes the objectives of stewardship "are likely to be framed in terms of equity, coverage, access, quality, and patients" 49 rights. Baldwin et al. note that stewardship means taking account of "different needs arising from factors such as age, gender, ethnic background or socio-economic status". ${ }^{50}$ Bolstering this is a focus on supporting population through the "conditions that allow people to be healthy, focussing attention, in particular, on reducing health inequalities". ${ }^{51}$ Finally, learning means using engagement around the other focal points to open up space for collective and especially institutional learning by the EU around uncertainty and ambiguity, the delineation of its responsibility, the production of governance distortions and failures, and ways of promoting the uptake and use in decision-making of the knowledge produced by citizen participation.

In drawing on stewardship models, supra-stewardship could derive power from their foundation in human rights and bioethics. While others have discussed the advantages and disadvantages of the link between them, 52 it is more important here to recognise its presence in several international declarations, ${ }^{53}$ and the scholarly discussion of what that

43 "Governance": www.who.int/healthsystems/topics/stewardship/en/index.html (emphasis added) (last accessed 5 September 2011).

44 "Message", n. 35 above, p. ix (emphasis added).

45 Nuffield Council, Public Health, n. 37 above, p. 68 (emphasis added).

46 Ibid.

47 Ibid. p. 67.

48 Ibid. p. 68.

49 "Governance", n. 43 above.

50 Baldwin et al., "Stewardship", n. 38 above, pp. 115-16. Cf. Nuffield Council, Public Health, n. 38 above, p. 25 (emphasis added).

51 Ibid. (emphasis added).

52 See, generally: Ashcroft, "Could human rights supersede bioethics?", n. 40 above.

53 For instance, the Universal Declaration on Bioethics and Human Rights (2005), and in the European context in, for instance, the Convention on Human Rights and Biomedicine (the Oviedo Convention 1997) and its protocols. 
entails. That is, as Ashcroft summarises, whether human rights might "subsume or replace bioethics, at least at the level of the public governance of medicine and the life sciences". 54 Most notable for present purposes is human rights' capacity, also noted by Ashcroft, and highlighted by Montgomery in his discussion of Nuffield, ${ }^{55}$ to facilitate communication between governance and citizens - as Black explains it, "putting the views of each set of participants [in governance] into a language that the others can understand" 56 - and to provide a rhetorical opening for participation.

Ashcroft describes the point of particular interest:

[The potential of human rights in the] hands of activists, at least to disrupt . . . by challenging the language, the types of problem recognised ... and the working methods of the public bioethics process. This might particularly be the case where the challenge to bioethics comes from groups which have tried - and failed - to challenge the policy consensus by other methods. 57

In relation to preparedness, and as detailed further in the next section, the groups that might benefit most include those whose biology or social status renders them particularly vulnerable to infection by pandemic influenza and who have a special interest in public health interventions, especially vaccination and social distancing. Figured as "risk groups", they include those with underlying medical conditions, pregnant women, children and itinerants. Such individuals and groups might exploit human rights 58 to generate "politics of life itself". 59 This potential is recognised in terms such as "moral pioneers", 60 "genetic citizens"61 or "biocitizens". ${ }^{62}$ These highlight how people come to know and understand themselves and relate to others through knowledge of their biological and medical status but nevertheless sometimes demonstrate "biosociality" 63 as they work together to reshape governance in order to address their concerns.

In the EU context, the empowering potential of human rights and bioethics has been traced more extensively by Flear and Vakulenko. ${ }^{64}$ Yet, that potential is stressed as replete with paradoxes and pitfalls that might reproduce and reinforce the deficit model of citizens - which might in turn stymie supra-stewardship. For instance, even as human rights promises and delivers results when deployed to combat social difference and its attendant

54 Ashcroft, "Could human rights supersede bioethics?", n. 40 above, at p. 640.

55 Cited as a work in progress and discussed in: J Coggon, "What help is a steward? Stewardship, political theory and public health law and ethics", in this special issue.

56 J Black, "Regulation as facilitation: negotiating the genetic revolution" (1998) 61(5) Modern Law Review 621, p. 623.

57 Ashcroft, "Could human rights supersede bioethics?", n. 40 above, p. 645 (emphasis added).

58 W Brown, States of Injury (Oxford: Princeton UP 1995); W Brown, "Suffering rights as paradoxes" (2000) 7 Constellations 230.

59 N Rose, The Politics of Life Itself: Biomedicine, power and subjectivity in the 21st Century (Oxford: Princeton UP 2007).

60 R Rapp, Testing Women, Testing the Fetus: The social impact of amniocentesis in America (London: Routledge 2000).

61 D Heath, R Rapp and K-S Taussig, "Genetic citizenship" in D Night and J Vincent (eds), A Companion to the Anthropology of Politics (Oxford: Blackwell 2004).

62 N Rose and C Novas, "Biological citizenship" in A Ong and S Collier (eds), Global Assemblages: Technology, politics, and ethics as anthropological problems (Oxford: Blackwell 2005).

63 P Rabinow, Essays on the Anthropology of Reason (Princeton NJ: Princeton UP 1996); S Gibbon and C Novas (eds), Biosocialities, Genetics and the Social Sciences (London: Routledge 2007).

64 Flear and Vakulenko, "A human rights perspective", n. 16 above. 
injustices, ${ }^{65}$ it can also produce and reinforce social position as identity. ${ }^{66}$ In moves that reinforce the deficit model, conferred top-down in the EU, ${ }^{67}$ human rights also depoliticises and naturalises the social origins of problems, and emphasises and abets moves towards self-management and individualisation that deny the potential of collective action to reshape governance. More broadly, Somsen queries the wisdom of developing a precautionary approach within human rights, arguing it effectively provides "governments with a blank cheque for limiting individual liberties". ${ }^{68}$ Similarly, stewardship might also limit individual autonomy through paternalistic interventions in citizens' lives.

Still, given the predominance of risk (and safety and security), human rights' efforts to engage and demonstrate its efficacy - here by instrumentalising public bioethics for citizen participation - is surely valuable. Further, safeguards against excessive action and paternalism in stewardship that might be deployed in supra-stewardship to resist disempowerment are envisaged by the WHO (especially in terms of patients' rights) and Nuffield. In the latter report, public health programmes are constrained by an intervention ladder that attempts to minimise "significant limitations on individual freedom". ${ }^{9}$ For example, while compulsory vaccination can override individual consent, its use should be minimised and come with procedural justice arrangements (such as democratic decisionmaking procedures) which provide adequate mandate and justification of public health governance. This sort of requirement provides resources for participation that could underpin supra-stewardship. Yet, since the focus is on aligning governance with public opinion through scrutiny and expression of views, and there are no guarantees for a substantive input into decision-making, participation is limited and there seems to be a denial of citizens' potential to contribute knowledge. ${ }^{70}$

To focus on (public) bioethics in the EU, it is prominent through the introduction of ethics committees in the MSs by the Clinical Trials Directive ${ }^{71}$ and the European Group on Ethics. The latter provides the Commission with a comprehensive range of opinions on "all areas of the application of science and technology", 72 which have been used to support controversial research funding ${ }^{73}$ and produce "whereas" clauses bolstering the recitals of

65 For instance, Article 6 amended TEU gives the previously non-binding Charter of Fundamental Rights of the European Union the same status as the treaties. Further, not only is the European Convention on Human Rights noted as a source for the general principles of EU law in Article 6(3) amended TEU, but the EU's accession to the Council of Europe is required under Article 6(2) amended TEU. It might even be said the EU - now with its own Fundamental Rights Agency - has become the human rights organisation in Europe. On this and key cases see: Flear and Vakulenko, "A human rights perspective", n. 16 above.

66 Flear and Vakulenko, "A human rights perspective", n. 16 above.

67 Ibid.

68 H Somsen, "Regulating human genetics in a neo-eugenic era" in T Murphy (ed.), New Technologies and Human Rights (Oxford: OUP 2009), p. 116.

69 Nuffield Council, Public Health, n. 37 above, p. 26.

70 Ibid. p. 26: stewardship "recognises the importance of open and transparent participatory processes as a necessary condition for public health policy making, but it is also clear that these are not sufficient by themselves. Stewardship is not exercised simply by following the public vote, especially where issues involve complex scientific evidence. Under the stewardship model, public health policy should be compatible with the views of the public, and the government should create conditions that allow the public to scrutinise and judge the appropriateness of proposed polices."

71 Directive 2001/20/EC.

72 Decision 2005/383/EC.

73 Opinion 10 - 11 December 1997 - Ethical Aspects of the 5th Research Framework Programme; Opinion 22 - 13 July 2007 - The Ethics Review of hESC FP7 Research Projects. 
legislation. ${ }^{74}$ In addition, the ethical content of the latter is removed from citizen contestation to be determined by committees and MS governments. ${ }^{75}$ Bioethics is designed "to ensure that the general public is kept properly informed" 76 and to "keep the rapidly advancing progress in science in harmony with the ethical values of all Europeans" ${ }^{77}$ Yet, since those values are merely represented in expert discourse, the deficit model of citizens re-emerges along with expert domination of governance. In short, bioethics has tended to be used less to facilitate citizen participation and more as a way of legitimating EU governance of life. Even so, as Flear and Vakulenko point out, bioethics has an empowering potential by opening up knowledge domains and facilitating discussion - and this could be enhanced by the link with human rights and references to mandate and participation. ${ }^{78}$

Overall, while stewardship models are, as Coggon asserts, neat but problematic labels, ${ }^{79}$ despite their problems and paradoxes, I stick to the basic proposition that suprastewardship is of much use as a tool to facilitate a discursive space for citizen participation in preparedness. Indeed, supra-stewardship might be most useful when deployed with critical self-consciousness to develop its content and meaning in light of ongoing concerns and immediate exigencies - and resist reproduction of the deficit model.

\section{EU preparedness: responsibility, governance distortions and failures}

\section{THE FRAME AND RATIONALITY OF PREPAREDNESS}

This will become apparent as I suggest how supra-stewardship could produce supplementary knowledge for existing technologies of hubris and contribute towards institutional learning and decision-making. As a first step, it is necessary to unpack the frame and rationality of preparedness in order to then suggest the contours of engagement on its delimitation of EU responsibility and some of its broad governance distortions and failures, which are brought out by attention to framing, distribution and vulnerability. In the second sub-section, I take a closer look at the boundaries of responsibility and distortions and failures relating to two key essential infrastructures favoured by preparedness: surveillance and interventions.

The frame is assembled from EU law and policy. As an indicative overview, in EU law public health is recognised and protected through express derogations to the free movement of goods, persons and services, which are supplemented by justifications created through the jurisprudence of the Court of Justice of the European Union. ${ }^{80}$ As such public health is central to the EU's internal market, defined as "an area without internal frontiers in which the free movement of goods, persons, services and capital is ensured". ${ }^{81}$ Public health

74 For instance, Directive 2004/23/EC on Human Tissue and Cells and Regulation 1394/2007 on Advanced Therapies.

75 M Tallacchini, "Governing by values. EU ethics: soft tool, hard effects" (2009) 47 Minerva 281, pp. $293-95$.

76 http://ec.europa.eu/bepa/european-group-ethics/archive-mandates/mandate-1991-1997/index_en.htm (emphasis added) (last accessed 5 September 2011) .

77 Taking European Knowledge Society Seriously: Report of the Expert Group on Science and Governance (Luxembourg: European Commission 2007), p. 49 (emphasis added).

78 Flear and Vakulenko, "A human rights perspective", n. 16 above.

79 Coggon, "What help is a steward?", n. 55 above.

80 For instance: Case 120/78 Rewe-Zentrale AG v Bundesmonopolverwaltung (Cassis de Dijon) [1979] ECR 649; Case 178/84 Commission v Germany (Beer Purity Laws) [1987] ECR 1227; Case C-76/90 Säger v Dennemeyer [1991] ECR I-4221; Case C-55/94 Gebhard [1996] ECR I-4165; Case C-237/94 O'Flynn v Adjudication Officer [1996] ECR I -2617. See further: C Barnard, The Substantive Law of the EU: The four freedoms (Oxford: OUP 2010), pp. 165-87, 241-2 and 510-8.

81 Article 26(2) TFEU (emphasis added). The establishment of the internal market is required by Article 3(3) amended TEU. 
is increasingly aligned to security concerns in the traditional understanding of them as being about containment, defence and protection, and also in a more Foucauldian vein as being about optimising the circulation of people and things and regulating the attendant dangers. This is apparent in, for instance, references that the MSs are "resolved to facilitate the free movement of persons, while ensuring the safety and security of their peoples, by establishing an area of freedom, security and justice". 82

This concern with security is inflected in Article 168 of the Treaty on the Functioning of the EU (TFEU), 83 the treaty base for preparedness, which states a "high level of human bealth protection shall be ensured in the definition and implementation of all Union policies and activities". ${ }^{84}$ EU action cannot harmonise and is only complementary to that of its MSs, ${ }^{85}$ which maintain responsibilities over "the definition of their health policy and for the organisation and delivery of health services and medical care". 86 However, the MSs are required to work in liaison with the Commission to coordinate among themselves their policies and programmes in the areas referred to in Article 168(1). ${ }^{87}$

Article 168(2) provides for the adoption of measures including guidelines and indicators, exchange of best practice, and mechanisms for periodic monitoring and evaluation. Under Article 168(1) and (2) such action must be "directed towards improving public health ... obviating sources of danger to physical and mental health", and covers "health information and education, and monitoring, early warning of and combating serious crossborder threats to health" 88 The addition of the final italicised portion to the text of the former Article $152 \mathrm{EC}$ seems intended to reflect and provide a concrete basis for EU action. Further, Article 168(3) provides both the EU and its MSs "shall foster cooperation with third countries and the competent international organisations in the sphere of public health". ${ }^{9}$

With EU law as its foundation, and grounded on a more general scientific approach to decision-making established in the EU White Paper European Governance as a response to the regulatory failures noted above, ${ }^{90}$ it is in policy that preparedness is elaborated. ${ }^{91}$ The focus on some of the most important steps in the tightening of the link between public health and security, 9/1192 and subsequent terrorist attacks prompted the EU's "all hazards"

82 Recital 12 amended TEU (emphasis added). Cf. Article 3(2) amended TEU. See further (including summary of legislation): http://europa.eu/pol/justice/index_en.htm (last accessed 5 September 2011). For discussion: N Walker (ed.), Europe's Area of Freedom, Security and Justice (Oxford: OUP 2004).

83 Formerly Article 152 EC.

84 Article 168(1) TFEU (emphasis added).

85 Harmonisation is precluded by Article 168(5) TFEU. In accordance with principles of subsidiarity and proportionality in Article 5 amended TEU.

86 Article 168(7) TFEU (emphasis added)

87 A concrete expression of the principle of sincere cooperation in Article 4(3) amended TEU.

88 Emphasis added. Previously Article 152(1)(1)-(2) EC emphasised "obviating sources of danger to human health" and it did not include a reference to cross-border threats to health.

89 Emphasis added.

90 For the EU's general approach to risk regulation see: European Commission, "European Governance: A White Paper", $\operatorname{COM}(2001) 428$ final. Cf. Flear and Vakulenko, "A human rights perspective", n. 16 above.

91 The documents are available at: http://ec.europa.eu/health/preparedness_response/policy/index_en.htm (last accessed 5 September 2011). On the link made globally see: Murphy and Whitty, "Is human rights prepared?", n. 19 above.

92 F Lentzos, "Rationality, risk and response: a research agenda for biosecurity" (2006) 1(4) BioSocieties 453. 
approach to biosecurity. ${ }^{93}$ With public health security established as a priority by the EU's Health Council on 15 November 2001, there followed a Programme of Cooperation on Preparedness and Response to Biological and Chemical Attacks [Health Security], ${ }^{94}$ dealing with deliberate human release of chemical, biological, radiological and nuclear (CBRN) agents within the EU and aimed at "bridging security and health". 95 One of the objectives of this plan was the establishment of the Health Security Committee (HSC), which meets twice yearly and is composed of high-level representatives from health ministries of the MSs, the Commission, the ECDC and the European Medicines Agency (EMA). ${ }^{96}$

On 27 November 2001, the Commission began its first notable foray into pandemic preparedness planning with a conference to link pandemic influenza with security (titled "Preparedness Planning in the Community: Influenza and Other Health Threats") and providing the impetus for next steps. ${ }^{97}$ With the concern around severe acute respiratory syndrome (SARS) and avian influenza in 2003, the link between public health and security came to encompass previously unknown diseases whose rapid transmission was facilitated by free movement. The importance of such measures was highlighted by the support and guidance of the WHO. ${ }^{98}$ In the wake of this, the remit of the Early Warning and Response System (EWRS) established in 199999 was extended to cover a wide range of communicable diseases, including H1N1.100 The EWRS is "a confidential computer system allowing Member States to send alerts about events with a potential impact on the EU, share information, and coordinate their response"101 (consistent with the

93 Cf. European Commission, "Green Paper on Bio-preparedness", COM(2007) 399 final. For discussion: S Brem and S Dubois, "Different perceptions, similar reactions: biopreparedness in the European Union" in P Katona, J P Sullivan and M D Intriligator (eds), Global Biosecurity: Threats and responses (London: Routledge 2010). More generally: D P Fidler and L O Gostin, Biosecurity in the Global Age: Biological weapons, public health, and the rule of law (Stanford: Stanford UP 2007); A Lakoff, "Preparing for the next emergency" (2007) 19(2) Public Culture 247; S Hinchcliffe and N Bingham, "Securing life: the emerging practices of biosecurity" (2008) 40(7) Environment and Planning A 1534.

94 European Commission, "Programme of Cooperation on Preparedness and Response to Biological and Chemical Attacks [Health Security]" G/FS D(2001) GG.

95 See: http://ec.europa.eu/health/preparedness_response/policy/index_en.htm (last accessed 5 September 2011). Subsequently, see: European Commission, "Communication on Cooperation in the European Union on Preparedness and Response to Biological and Chemical Agent Attacks (Health Security)", COM(2003) 320 final. Also see: European Commission, "Communication on Strengthening Chemical, Biological, Radiological and Nuclear Security in the European Union - an EU CBRN Action Plan", COM(2009) 273 final; European Commission, "Commission Staff Working Document on Strengthening Chemical, Biological, Radiological and Nuclear Security in the European Union - an EU CBRN Action Plan. Impact Assessment", SEC(2009) 790; European Commission, "Commission Staff Working Document on Strengthening Chemical, Biological, [n. 95 cont.] Radiological and Nuclear Security in the European Union - an EU CRBN Action Plan. Summary of Impact Assessment", SEC(2009) 791; European Commission, "Commission Staff Working Document Bridging Security and Health: Towards the Identification of Good Practices in the Response to CBRN Incidents and the Security of CBR Substances", SEC(2009) 874.

96 Especially representatives of Directorate-General for Health and Consumers: http://ec.europa.eu/dgs/health_consumer/index_en.htm (last accessed 5 September 2011).

97 http://ec.europa.eu/health/ph_threats/com/Influenza/influenza_conference_1.htm (last accessed 5 September 2011).

98 European Commission, "Communication on Strengthening Coordination on Generic Preparedness Planning for Public Health Emergencies at EU Level”, $\operatorname{COM}(2005) 605$ final, p. 3.

99 Decision 2119/98/EC Establishing Network for the Epidemiological Surveillance and Control of Communicable Diseases and Decision 2000/57/EC11 on the EWRS.

100 http://ec.europa.eu/health/communicable_diseases/diseases/index_en.htm\#A (last accessed 5 September 2011).

101 http://ec.europa.eu/health/communicable_diseases/early_warning/comm_legislation_en.htm (last accessed 5 September 2011). 
International Health Regulations). ${ }^{102}$ Surveillance data from the EWRS is collated into a report by the ECDC. ${ }^{103}$ This move strengthened the knowledge available to MSs and enhanced their ability to limit contagion.

On 26 March 2004, the Commission began to step up its engagement with pandemic influenza planning, and as an "important step" established a Public Health Preparedness and Response Planning Group (PHPRPG) in the HSC to advise it on the actions to be taken in the event of an imminent pandemic threat. ${ }^{104}$ On 28 November 2005, there followed the Communication on Pandemic Influenza Preparedness and Response Planning in the European Community, ${ }^{105}$ which updated planning in light of WHO recommendations and the establishment of the ECDC, also in 2005. This uses "the principles and components of . . . generic preparedness planning", ${ }^{106}$ such as in the Communication on Strengthening Coordination on Generic Preparedness Planning for Public Health Emergencies at EU Level 107 and the Interim Document: Technical Guidance on Generic Preparedness Planning for Public Health Emergencies (interim document). ${ }^{108}$ As such, I draw on generic preparedness only where it helps to elaborate on pandemic preparedness. The Commission and the ECDC have also been actively engaged with the WHO, joint international workshops ${ }^{109}$ and global meetings to discuss planning with third countries, ${ }^{110}$ including the Global Health Security Initiative (GHSI), an informal, international partnership that works to strengthen health preparedness and response globally. ${ }^{111}$

Importantly, in February 2007, the Health Council agreed on a transitional prolongation and extension of HSC's mandate to encompass the threads traced above: public health preparedness and response to CBRN attacks; generic preparedness and response for public

102 The International Health Regulations (IHR) require WHO MSs to notify the WHO of any potential international public health emergency (World Health Assembly, International Health Regulations (2005), available at www.who.int/csr/ihr/IHRWHA58_3-en.pdf (last accessed 5 September 2011)), and are rendered applicable to the EU under Article 57(1) IHR, which states the IHR and EU Treaties "should be interpreted so as to be compatible". The Commission "believes the EU and its [MSs] can and should work together to optimise IHR implementation in the context of the EU policies and health related actions and initiatives" (see press release: http://europa.eu/rapid/pressReleasesAction.do?reference=IP/06/1276 (last accessed 5 September 2011)).

103 For instance, Annual Epidemiological Report on Communicable Diseases in Europe 2009 (Stockholm: ECDC 2010), available at http://www.ecdc.europa.eu/en/publications/Publications/1011_SUR_Annual_Epidemiological_ Report_on_Communicable_Diseases_in_Europe.pdf (last accessed 5 September 2011).

104 See http://ec.europa.eu/health/ph_threats/com/Influenza/influhome/influenza_level_en.htm (last accessed 5 September 2011).

105 European Commission, "Communication on Pandemic Influenza Preparedness and Response Planning in the European Community”, $\operatorname{COM}(2005) 607$ final.

106 Ibid. p. 7.

107 European Commission, "Generic Preparedness", n. 98 above.

108 European Commission, “'Interim Document': Technical Guidance on Generic Preparedness Planning for Public Health Emergencies", 2005. This addresses in martial tones, "threats and emergencies which are affecting or are likely to affect public health in more than one Member State” (ibid. p. 65, emphasis added). The guidance includes checklists "as a guide that may be used to assist in the development, revision or assessment of comprehensiveness of preparedness plans" (ibid. p. 3) and facilitate the "inter-operability of national plans, mainly by the creation of co-ordination mechanisms and analysis and communication tools that enbance co-operation between key Member States and Commission players" (ibid. p. 2, emphasis added), and lay the basis for "reviews, validations and tests and making recommendations for improvements and fine-tuning of national plans and EU procedures to reduce vulnerabilities and incompatibilities" (ibid. emphasis added).

109 2-3 March 2005 in Luxembourg, 24-26 October 2005 in Copenhagen, 15-17 May 2006 in Uppsala, and 25-27 September 2007 in Luxembourg. See further: http://ec.europa.eu/health/ph_threats/com/ Influenza/influhome/influenza_level_en.htm (last accessed 5 September 2011).

110 For instance, "Vienna Senior Officials Meeting on Avian and Human Pandemic", 6 and 7 June 2006. See http://ec.europa.eu/health/ph_threats/com/Influenza/SOM_Vienna.pdf (last accessed 5 September 2011).

111 See www.ghsi.ca/english/index.asp (last accessed 5 September 2011). 
health emergencies; and, most significantly, influenza preparedness and response. ${ }^{112}$ The link between public health and security was augmented further by the identification of "protecting people from health threats" as one of three key objectives of 2007's Together for Health: A Strategic Approach for the EU 2008-2013.113 This encompasses communicable, noncommunicable and rare diseases, vaccination, and preparedness and response to health threats.

Preparedness operationalises, and is framed by, this dense link between public health and security in order to deal with a pandemic, which is constructed as a medical emergency. It is a useful supplement to public health's traditional focus on prevention, which relies on archival-statistical knowledge, but which by definition becomes of limited use in contexts of high uncertainty. Unsurprisingly, then, preparedness is the pervasive governance response for dealing with highly ambiguous and uncertain (low-probability, high-harm) risks, ${ }^{114}$ engendering a "policy revolution", 115 propelling us into "the age of preparedness". 116 As Collier and Lakoff put it, generally preparedness requires imaginative enactment and "demands that experts constantly assess the vulnerability of vital systems and the readiness to respond to, and recover from, events that threaten them". ${ }^{117}$ This is echoed by the Commission, which uses previous experience to imagine pandemic scenarios 118 and notes "the ability to respond to an international threat to health is profoundly influenced by the extent to which the issues have been considered in advance and plans are in place for co-ordinated action".119

Yet, as Collier and Lakoff go on to say, generally the goal of preparedness "is not necessarily to prevent events from happening but to mitigate their consequences - in other words, to keep a disaster from turning into a catastrophe".120 This is reflected in statements by the Commission. For example, preparedness is "directed towards identifying and addressing the current impact and subsequent threat potential of the influenza outbreak in order to limit its consequences" 121 - especially to the internal market. ${ }^{122}$ Still, in producing a "synergy" to the mutual benefit of public health and security such as in relation to surveillance and interventions, preparedness might have some use in bolstering efforts and resources to deal with pandemics as a medical emergency. ${ }^{123}$ Indeed, as Rothstein et al. point out, a focus on so-called "institutional risk" (the "government of governments") can

112 In response to: European Commission, "Communication on Transitional Prolongation and Extension of the Mandate of the Health Security Committee in View of a Future General Revision of the Structures Dealing with Health Threats at EU Level", $\operatorname{COM}(2006) 699$ final.

113 European Commission, "White Paper, Together for Health: A Strategic Approach for the EU 2008-2013", $\operatorname{COM}(2007) 630$ final; European Commission, "Commission Staff Working Document Accompanying White Paper, Together for Health: A Strategic Approach for the EU 2008-2013”, SEC(2007) 1376. For an overview of initiatives, see European Commission, "Commission Staff Working Document, Report on European Governance (2003-2004)”, SEC(2004) 1153. Also see: http://ec.europa.eu/health/strategy/policy/ index_en.htm (last accessed 5 September 2011).

114 R Ericson and A Doyle, Uncertain Business: Risk, insurance and the limits of knowledge (Toronto: University of Toronto Press 2004); S J Collier, "Enacting catastrophe: preparedness, insurance, budgetary rationalization" (2008) 37(2) Economy and Society 224; A Lakoff, "From population to vital system" in A Lakoff and S Collier (eds), Biosecurity Interventions (Chichester: Columbia UP 2008); P O'Malley, Risk, Uncertainty and Government (London: Glasshouse Press 2004).

115 Fidler and Gostin, Biosecurity, n. 93 above, p. 145.

116 Murphy and Whitty, "Is human rights prepared?", n. 19 above, pp. 230 and 232.

117 S Collier and A Lakoff, "Vital systems security" (2007) ARC Working Paper No 2, p. 3 (emphasis added).

118 For instance, European Commission, “Interim Document”, n. 108 above.

119 Ibid. p. 3 (emphasis added).

120 Ibid.

121 European Commission, "Pandemic Influenza Preparedness", n. 105 above, p. 8 (emphasis added).

122 Ibid. and European Commission, "Interim Document", n. 108 above.

123 See further, Fidler and Gostin, Biosecurity, n. 93 above, ch. 5. 
figure the approach taken to "societal risks" (like H1N1). ${ }^{124}$ Advantages of this include the sensitisation of the EU to pandemic influenza, more and coordinated research, professionalisation of the problem and a stronger basis for decision-making.

However, such potential benefits are what de Larrinaga and Doucet call "part of the wager" of securitisation of public health by and through the construction of a pandemic as a medical emergency. ${ }^{125}$ Securitisation is a speech act and force that redounds below, especially in relation to distribution and vulnerability concerns around interventions. Security provides the "conditions of possibility for liberalism's central tenet of freedom", 126 what Foucault describes as "the possibility of movement, change of place, and processes of circulation of both people and things". 127 As such, optimisation of freedom creates demands for increased security and an all too easy resort to the exceptional measures it favours - that is, more preparedness through a focus on protection of essential infrastructures, especially surveillance and interventions. ${ }^{128}$ Balzacq summarises the point: the "social design of a security problem conditions and legitimates the kind of means used to stop it" and as such it is a "normative political act". 129

Moreover, as de Larrinaga and Doucet explain, the governmentalisation of security means it is increasingly understood in neoliberal terms as being about the optimisation of the health and wealth of (non-state) populations and "assessment of threats ... pays particular attention to the global and transboundary circulation of threats to [them]". ${ }^{130}$ In a reflexive way this is to be achieved through the protection of vulnerable governance rather than vulnerable populations. As already apparent, and detailed further below, this is accomplished by assembling, linking together and leveraging support from various discourses, knowledges, scientific and bureaucratic techniques and practices from a range of national, supranational and global actors and sources. ${ }^{131}$ References to inter alia the Commission, HSC, ECDC, MSs, WHO and GHSI, and their gathering and deployment of pandemic and risk knowledge, highlight the securitisation of public health and governmentalisation of security as being underpinned by an expert rationality.

To clarify, the broadest governance distortion is the emphasis on and distribution of resources towards protecting essential infrastructures - planning and coordination, monitoring and assessment, prevention and containment, health system response and communication - which attempt to mitigate catastrophe in the face of a pandemic medical emergency and ensure the EU is only indirectly formally responsible for population. To quote Black, this also sets in train "decisions as to which types of failures an organisation is willing to tolerate" - failures in the direct protection of population - "and

124 H Rothstein, M Huber and G Gaskell, "A theory of risk colonization: the spiralling regulatory logics of societal and institutional risk" (2006) 35(1) Economy and Society 91.

125 M de Larrinaga and M G Doucet, Security and Global Governmentality: Globalisation, governance and the state (London: Routledge 2010), p. 1.

126 Ibid. p. 7.

127 Foucault, Security, n. 26 above, pp. 48-9.

128 Generally, see De Larrinaga and Doucet, Security and Global Governmentality, n. 125 above.

129 T Balzacq, "Preface" in Securitisation Theory: How security problems emerge and dissolve (London: Routledge 2011), p. xiii.

130 De Larrinaga and Doucet, Security and Global Governmentality, n. 125 above , p. 17 (emphasis added).

$131 \mathrm{~J}$ Huysmans, The Politics of Insecurity: Fear, migration and asylum in the EU (London: Routledge 2006). 
which it is not"132 - failures in the protection of essential infrastructures in order to optimise the economy.

As Black continues, these choices "are linked to attempts to define the parameters of blame. Through risk-based frameworks, regulators are attempting to define what, to their minds, are the acceptable limits of their responsibility and hence accountability". ${ }^{133}$ It does not appear that improvisation ${ }^{134}$ is to be avoided or eliminated even as interoperability of MS plans is the focus, and given that, as traced below, it is built into planning. However, improvisation does seem to be constrained - and responsibilities limited to protection of essential infrastructures in order to optimise the economy, governance distorted and certain failures envisaged - by the construction of preparedness. Requiring far more discussion, below I focus only on pharmaceutical interventions as the key medical emergency triage choice. Clearly, attention to framing reveals the pandemic "threat", the governance planning response, and its attendant distortions and failures as fabrications with profound normative implications. Yet, as Balzacq states, "those who define a threat can be held accountable, as threats" - and planning, its attempted limitation of responsibility and production of governance distortions and failures - "are also the product of their entrepreneurship". 135

Reference to the alert phases helps to bring out the centrality and importance of the focus on the protection of essential infrastructures. To overview the phases, they are based on EU generic planning alert phases, which are in turn based explicitly on WHO Phases 1-6. The inter-pandemic period is at Phases 1 and 2. At this stage no new influenza virus subtypes have been detected in humans, but they might be present in animals. The main public health goal at this stage is to "strengthen influenza pandemic preparedness at the global, regional, national and sub-national levels"136 and minimisation of the risk of transmission to humans. This requires rapid detection and reporting of any such transmission. The Commission and the ECDC work in consultation with the HSC, and in cooperation with the WHO, to assess, review and organise "exercises concerning national pandemic plans, with a special focus on their interoperability". 137

Phases 3 to 5 are the pandemic alert period. At Phases 3 and 4, there are no human cases in the EU, but a risk of sporadic importation of isolated cases in MSs. Rapid characterisation of the new virus subtype and early detection, notification and response to new cases are the main public health objectives. At Phase 4, containing the new virus within a limited area or delaying its spread in order to implement preparedness counter-measures, such as the development of vaccine, is the main public health objective. At Phase 5, there are larger clusters of cases outside the EU, but human-to-human contagion is still limited in area. The main public health objective is to "maximize efforts to contain or delay spread, to possibly avert a pandemic, and to gain time to implement pandemic response measures". 138

$132 \mathrm{~J}$ Black, "The emergence of risk-based regulation and the new public risk management in the United Kingdom" (2005) Public Law 512, p. 513 (emphasis added). On failure cf. J Downer, "Anatomy of disaster: why some accidents are unavoidable" (2010) CARR Discussion Paper 61.

133 Ibid. p. 514 (emphasis added).

134 Cf. G Gorgoni, “'(Pre)caution Improvisation Area': Improvisation and responsibility in the practice of the precautionary principle" (2010) 6(1) Critical Studies in Improvisation at: www.criticalimprov.com/ article/view/1086/1727 (last accessed 5 September 2011). Thanks to Thérèse Murphy and Sara Ramshaw for these insights.

135 Balzacq, "Preface", n. 129 above, p. xiii (emphasis added).

136 European Commission, "Pandemic Influenza Preparedness", n. 105 above, p. 16.

137 Ibid.

138 Ibid. p. 21. 
Phase 6 is the pandemic period in which there is now an increased and sustained transmission of cases around the world and in the EU's general population. The main public health objective is minimising the pandemic's impact in the EU. In order to do so, the EU adopts its own Alert Levels 1-4. These take into account specifics such as the absence of internal borders, and differences between MSs (southern and eastern MSs have higher susceptibility). At EU Alert Level 1 there are no human cases in the EU, but there is a very high risk of sporadic imported cases. At EU Alert Level 2 there is a single human case inside the EU. EU Alert Level 3 occurs when there is an isolated cluster in one EU MS or sustained transmission between humans with several clusters inside the EU. EU Alert Level 4 is when there are cases in one or more MSs.

This phasing serves to modulate and shape preparedness by further specifying and limiting responsibilities and (improvisation of) actions in response to events towards, and establishing the boundaries of accountability and blame for failures in, the protection of essential infrastructures. For example, planning and coordination is aimed at "improving coordination and communication" to ensure the EU is of "added value". 139 The PHPRPG is required to review MS preparedness plans and ensure the identification and dissemination of "expertise and good practice"140 and the EWRS must be used for notification of cases and exchange of information on measures taken.

The ECDC sets the terms of reference for Outbreak Assistance Teams (OATs). ${ }^{141}$ These participate in "outbreak investigation inside and outside the Community ensuring coherence and synergies with the EU's external response in co-operation with the WHO". ${ }^{42}$ Generally, the Commission is responsible for reviewing its own internal contingency and coordinating guidance to national authorities so that they can review and update their plans in light of evidence. ${ }^{143}$ More specifically, at Phase 5, Commission staff surge capacity must be ensured, and at Phase 6 a centre to coordinate EU and international level actions and evaluate effectiveness must be established. Surveillance is dealt with in monitoring and assessment, and it provides the information upon which hinges the alert threat-level and the use of countermeasures such as vaccines. Indeed, "early detection and characterisation of pandemic strains"144 is the "most important"145 task. I elaborate on this, and interventions dealt with in prevention and containment, in the second sub-section.

To reflect further, the limitation of responsibility to the focus on, and distribution of resources towards, protecting essential infrastructures, such as surveillance, surge capacity and, as emphasised below, interventions like pharmaceuticals as the preferred triage choice, masks and is detrimental to wider public health objectives and increases the vulnerability of those who lose out as a consequence. Francis et al. point out how, while the "apparent assumption that devoting resources to pandemic planning is just" might be explained by the openness of the "triage choices in pandemic planning", nevertheless

\footnotetext{
139 European Commission, "Pandemic Influenza Preparedness", n. 105 above, p. 8.

140 Ibid.

141 Ibid.

142 Ibid.

143 Ibid. p. 17

144 Ibid. p. 8.

145 Ibid.
} 
"there are serious questions of justice to be asked about the allocation of extensive resources to pandemic threats." 146

Indeed, Fidler and Gostin note that preparedness might skew resources towards rare events like pandemic influenza "at the expense of tackling health problems that cause the great death and illness in populations daily". ${ }^{147}$ Similarly, others stress that preparedness might skew resources towards communicable diseases at the expense of non-communicable diseases and persistent public health problems. ${ }^{148}$ This is perhaps of greater concern in terms of external relations. There are efforts at international collaboration, especially with poorer countries, such as in relation to pharmaceuticals, elaborated below, and the ECDC's organisation and deployment of OATs abroad. Yet the EU's focus on protection becomes nuanced to being about its essential infrastructures. This could be mirrored in external effects by skewing resource allocation in countries with already poorly equipped health-care systems towards protection of their essential infrastructures, but in order to protect the EU. This is ultimately to the detriment of their already strained public health capacities and vulnerable populations.

Moreover, it is noteworthy that prior to Phase 6 the EU is deemed free of pandemic infection. This amounts to an externalisation of public health problems caused by failures of law, policy and medical practice in the EU, such as so-called MRSA and C difficile, ${ }^{149}$ which are naturalised as part of the order of things, and consequently there is no one to blame. Despite efforts at international cooperation there remains a bias towards EU needs and the idea that, rather than being endemic to the operation of the EU's privileging of free movement, the "threat" comes from "out there". In short, there is much need for highlighting concerns around framing, distribution and vulnerability in order to avoid "myopia". ${ }^{150}$ As Murphy and Whitty explain, without attention to broader social conditions and public health concerns, such as sufficient staff and resources overall and reducing inequalities, "global surveillance, surge capacity and, more generally, preventing and coping with a pandemic will be all the more difficult". 151

Four main imbricating forces are worthy of attention given they might work to undergird and reinforce the delineation of responsibility and production of governance distortions and failures. A first force is a more specific valence of securitisation. To quote de Larrinaga and Doucet, security is increasingly prevalent and powerful, as indicated by the way in which "greater security" has come to trump so easily other available political discourses". ${ }^{152}$ Linked closely to this is a second force: the dissemination of the wider zerosum relationship between human rights and risk (and safety and security). Lazarus and Goold observe the power of "the idea that certain human rights can be 'turned off' when necessary" has become a "thoroughly reasonable reaction to the dangers allegedly faced by

146 L P Francis, M P Battin, J A Jacobson and C B Smith, "Pandemic planning and distributive justice in health care" in M Freeman (ed.), Law and Bioethics (Oxford: OUP 2008), p. 433 (emphasis added). Cf. consideration of social justice in pandemic planning in: "Bellagio Statement of Principles", available at: www.unicef.org/avianflu/files/Bellagio_Statement.pdf and www.bioethicsinstitute.org/web/page/905/ sectionid/377/pagelevel/3/interior.asp (last accessed 5 September 2011).

147 Fidler and Gostin, Biosecurity, n. 93 above, p. 8.

148 D Yach, S R Leeder, J Bell and B Kistmasamy, “Global chronic diseases” (2005) 307 Science 317.

149 S Jenkins, "Swine flu? A panic stoked in order to posture and spend", The Guardian, 29 April 2009.

150 Cf. Francis et al., "Pandemic planning and distributive justice in health care", n. 146 above, p. 446.

151 Murphy and Whitty, "Is human rights prepared?", n. 19 above, at 243.

152 De Larrinaga and Doucet, Security and Global Governmentality, n. 125 above, p. 1 (emphasis added). 
democratic societies". 153 Abetting this is a broader tendency stressed by Hunter in which "all aspects of health emergency policy have shifted towards the framework of enhanced executive authority". 154 Going so far as to describe this zero-sum game as part of the "new "rights revolution", 155 Murphy and Whitty note "there are no guarantees that the securitisation of public health, the right to security or human security will be good for human rights". 156

What Rothstein et al. term "institutional risk" also has another valence and it is the third force. That is, a focus on institutional risk might transform and reduce preparedness techniques into instrumental tick-box exercises and be detrimental to the efficient management of the societal risk of pandemics. Wider moves towards reflexive governance $-a$ focus on inter alia institutions and their means of action - might exacerbate and underpin this focus on institutional risk. Since the object of these various moves is economic optimisation, they might also ensure governance openly serves the economy. Below I suggest this is apparent in the preference for protection of pharmaceutical interventions.

To tease out the point about legitimation, this final main force is especially important in light of inter alia the failures noted above leading to the EU's renewed interest in risk governance in European Governance, successive democratic rejections of Treaty amendments, and a wider "democratic deficit". ${ }^{157}$ Preparedness helps to constitute and project the EU's identity as authoritative and useful to its citizens, MSs, international actors and private actors like corporations, especially given worldwide moves towards "greater security". Preparedness and its attendant distortions and failures might be augmented and facilitated by the resources and openings for action and the production of "output" legitimacy ${ }^{158}$ it provides.

In other words, constructing pandemic influenza as a "threat" in a medical emergency model, and then a "risk" that must be governed in the present, ${ }^{159}$ enlarges power and the possibility of action ${ }^{160}$ - and, as noted, it conditions and legitimates the means used. As a twist, Power observes that democratic ideals "are increasingly positioned within ideals for good governance of the risk analysis process". 161 This highlights preparedness as being partly about rendering the EU auditable and inspectable - and relating to and managing

153 L Lazarus and B J Goold, "Security and human rights: the search for a language of reconciliation" in B J Goold and L Lazarus (eds), Security and Human Rights (Oxford: Hart 2007), p. 4. Also see: G J Annas, American Bioethics: Crossing buman rights and health law boundaries (Oxford: OUP 2005); L O Gostin, "When terrorism threatens health: how far are limitations on personal and economic liberties justified?" (2003) 55 Florida Law Review 1105; I Loader and N Walker, Civilising Security (Cambridge: CUP 2007); B Von Tigerstrom, Human Security and International Law: Prospects and problems (Oxford: Hart 2007).

154 N Hunter, "'Public-private' health law: multiple directions in public health" (2007) 10 Journal of Health Care Law and Policy 101, p. 106 (emphasis added).

155 Murphy and Whitty, "Is human rights prepared?”, n. 19 above, p. 231. Also see T Murphy, “Taking revolutions seriously: rights, risk and new technologies" (2009) 16(1) Maastricht Journal of European and Comparative Law $15-39$.

156 Murphy and Whitty, "Is human rights prepared?", ibid. p. 232.

157 In general, see C Scott, "Accountability in the regulatory state" (2000) 27 Journal of Law and Society 38; F Scharpf, Governing in Europe. Effective and democratic? (Oxford: OUP 1999); A Arnull and D Wincott, Accountability and Legitimacy in the European Union (Oxford: OUP 2002).

158 Scharpf, Governing in Europe, ibid.

159 Cf. Lentzos, n. 92 above, p. 461. F Ewald, "Insurance and risk" in G Burchell, C Gordon and P Miller (eds), The Foucault Effect. Studies in governmentality (Chicago: University of Chicago Press 1991).

160 S Sontag, Illness as Metaphor and AIDS and its Metaphors (London: Penguin 1991), especially p. 175.

161 M Power, Organized Uncertainty (Oxford: OUP 2007), p. 20 (emphasis added). 
"public expectations". ${ }^{162}$ More specifically, risk - and preparedness - is partly an exercise in governing "unruly perceptions" and maintaining the "production of legitimacy in the face of these perceptions". 163

Relating to and managing public expectations occurs principally through communication, itself an essential infrastructure. This draws on the general approach established in European Governance in which openness, transparency, and accountability are to be ensured, and governance legitimated, by inter alia the provision of up-to-date and easily available (principally online) information on EU law and policymaking and, in preparedness, pandemic news media "status" updates. ${ }^{164}$ Each alert phase has its own communication plan, reflecting the seriousness of the threat, and based on information gathered through surveillance. For example, throughout the alert phases it is for MS authorities to communicate arrangements for vaccination and distribution of antiviral agents to health professionals and the public.

Further, at Phase 3 the Commission, the ECDC and MSs must work together in order to coordinate the sharing of "accurate messages" about, inter alia, the global epidemiological situation (including spread and effectiveness of counter-measures). At Phase 4 (and similarly at Phases 5 and 6) the Commission and ECDC must work to promote "sharing of templates for general health education materials" 165 and the MSs must share their intended "public and educational material". 166 The ECDC is charged with providing "the scientific appraisal of recommended measures" 167 and, as stressed at Phase 6, it has a central role in making briefings from the EU to other actors, including the public.

Fast exchange of information and:

prompt notification during the first stages of a pandemic influenza are essential in enabling [MSs], the Commission, the ECDC, WHO and other bodies to respond with common positions in public communications, and alert properly their structures, so that measures can be implemented in a timely manner. ${ }^{168}$

As such, MS public authorities should "communicate effectively with the public and the media before and in anticipation of events that may lead to public health emergencies". 168a Messages are to be coordinated, ${ }^{169}$ and this should occur early on in any major incident, so as to ensure they establish "themselves as the leading, if not the only, source of authoritative information", 170 and so as to avoid an "information void"171 and subsequent speculation, rumour and confusion. This is facilitated through a "range of ready to use media briefing

162 Power, Organized Uncertainty, n. 161 above, pp. 20-1.

163 Ibid. p. 21 (emphasis added). Of course, besides citizens other addressees of the demonstration of action afforded by the rhetoric of preparedness include the MSs and international actors such as the WHO and GHSI (all leveraging support from EU action).

164 For instance, http://europa.eu/press_room/press_packs/influenza/index_en.htm; www.ecdc.europa.eu/en/ healthtopics/influenza/Pages/index.aspx; http://ec.europa.eu/health/communicable_diseases/diseases/ influenza/h1n1/index_en.htm (all last accessed 5 September 2011).

165 European Commission, "Pandemic Influenza Preparedness", n. 105 above, p. 20.

166 Ibid. p. 21.

167 Ibid.

168 Ibid. p. 14 (emphasis added). Cf. European Commission, "Generic Preparedness", n. 98 above, p. 6.

168a European Commission, "Generic Preparedness", ibid. p. 7 (emphasis added).

169 For instance, the Commission's October 2005 technical guidance document on Procedure for Communication to Member States, the Commission and the ECDC about Highly Pathogenic Avian Influenza Events in Humans, cited in European Commission, "Pandemic Influenza Preparedness", n. 105 above, p. 14.

170 European Commission, "Generic Preparedness", n. 98 above, p. 7.

171 Ibid. p. 13. 
materials about influenza", ${ }^{172}$ including, basic information about the disease and the response systems in place, and clear and timely flows of information facilitated by 24/7 "operational contact points in the Member States and in the Commission", 173 and encompassing "text, voice, and video". ${ }^{174}$

In relating to and managing public expectations, communication is concerned with establishing and limiting the boundaries of EU responsibility and blame in the public imagination to failures in the protection of finite and easily identifiable essential infrastructures and legitimating governance and the means used to deal with a pandemic medical emergency. The rhetoric of risk is, to quote Black, a "useful legitimating device". ${ }^{175}$ The EU is able to produce legitimacy through its centrality to communication, and in a neoliberal vein it does so through ensuring the output of an optimised and secure internal market: the "distribution of accurate and timely information . . . is critical in order to minimise unwanted and unforeseen social disruption and economic consequences and to maximise the effective outcome of the response". ${ }^{176}$ Such a focus might reinforce the zero-sum relationship between human rights and risk (and safety and security) and the legitimacy of using means favoured by security.

A focus on output legitimacy is also abetted by the limited construction of citizens within the deficit model as key addressees of communication. That is, consistent with Article 168(1)(2), preparedness relates to, animates and manages citizens through health information and education materials. It is noted that it:

will help reinforce public confidence in the response strategy if Member States and the Commission can demonstrate that the national strategies across the EU are consistent and based on a common assessment of the relevant science. ${ }^{177}$

This statement also reveals the limited nature of democratic ideals within risk governance. Communication is used to produce limited "input" in order to support and authorise preparedness. As such, this public rationality complements and buttresses the expert rationality, its depoliticisation and naturalisation of preparedness, the limited boundaries of responsibility, and the production of governance distortions and failures. Citizens do, however, have some input through surveillance and information-gathering. Yet, even then citizens are only one source among many, ${ }^{178}$ and participation does not appear to extend to shaping and directing the form and broader focus of governance, or to identifying its distortions and failures.

This betrays an inflection with PUS which is also found in documents constituting the EU's overarching approach to risk governance, especially European Governance and Science and Society. ${ }^{179}$ PUS is an instrument used to support the overarching agenda of producing

172 European Commission, “Generic Preparedness", n. 98 above, p. 13.

173 Ibid. p. 7.

174 Ibid. p. 6.

$175 \mathrm{~J}$ Black, "The emergence of risk-based regulation and the new public risk management in the United Kingdom", n. 132 above, p. 519. Also see: J Black, "Constructing and contesting legitimacy and accountability in polycentric regulatory regimes" (2008) 2 Regulation \& Governance 137.

176 European Commission, "Generic Preparedness", n. 98 above, p. 6.

177 European Commission, "Pandemic Influenza Preparedness”, n. 105 above, p. 14 (emphasis added).

178 Ibid.

179 European Commission, "Science and Society Action Plan", COM(2001) 714. See also European Commission, "Commission Staff Working Paper, Science, Society and the Citizen in Europe", SEC(2000) 1973; European Commission, "Science and Technology, the Key to Europe's Future: Guidelines for Future European Union Policy to Support Research”, COM(2004) 353 final. 
economic optimisation. ${ }^{180}$ Perhaps the most notable PUS technique used in preparedness is the Eurobarometer on attitudes to pandemic planning. ${ }^{181}$ Another is questionnaires, for instance, through the Stakeholder Consultation on Strengthening European Union Preparedness on Pandemic Influenza. ${ }^{182}$ These are used to produce statistics and reports on strengthening governance. They conjure citizens, their understanding of pandemic science, and therefore the appropriate relationship between citizens and governance (which reinforces the importance of "tooling-up" through supra-stewardship). So-called "absent presences",183 citizens are represented and imagined by EU actors in order to provide a democratic basis for their decisions. Importantly, PUS is controlled by experts who attempt to shape and define citizen and "public" identities and attitudes within the deficit model as being in need of education. 184 Such a prior framing of public understanding denies the normative dimension of preparedness and attempts to "mark off" governance from popular control and contestation.

Overall, the complementary expert and public rationalities in preparedness highlight how, to quote Walklate and Mythen's observation, "expert institutions deploy discourses of risk to filter information, buttress dominant norms and to muffle political opposition".185 This tendency might be reinforced by the way in which preparedness literally governs and attempts to quiet citizens through their feelings of insecurity. 186

\section{A CLOSER LOOK AT SURVEILLANCE AND INTERVENTIONS}

Citizens could also hone supra-stewardship to take a closer look at surveillance and interventions. Here, I focus on some further contours for engagement that highlight how the framing of preparedness as being about dealing with a medical emergency impacts on distribution and vulnerability. Beginning with and elaborating on surveillance, throughout the alert phases, the ECDC works with the Commission, other EU agencies and MS authorities to coordinate epidemiological surveillance, especially through the EWRS.187 Surveillance information is used to identify the circumstances of infection and to produce "risk groups". These might be subject to containment and control measures, discussed below as interventions. At Phase 4, the risk groups and counter-measures are put under enhanced surveillance, and this attention heightens at Phase 5 when there might be importation of cases, and again at Phase 6 with the circulation of the pandemic in the EU.

180 Jasanoff, Designs on Nature, n. 11 above, p. 251.

181 See http://ec.europa.eu/health/communicable_diseases/diseases/influenza/h1n1/docs/eurobarometer _summary_20100224.pdf (last accessed 5 September 2011).

182 See http://ec.europa.eu/health/preparedness_response/consultations/preparedness_cons_01_en.htm (last accessed 5 September 2011). Answers are sought to two key questions: how useful was the 2005 plan both during the pandemic preparedness phase and during the response to pandemic (H1N1) 2009 and how should it be improved? What should be done at EU level to improve EU pandemic preparedness? However, the focus is on: preparedness and co-ordination, surveillance, containment and mitigation (including vaccines and antivirals), health system response, international communication and communication with citizens. The final section is about multi-sectoral preparedness, which has been highlighted as an area for development. Overall, apart from the final section, the questionnaire is prefigured by what went before - and the questions asked do not seek to elicit a substantive input into preparedness besides this standalone consultation. The impression is that the deficit model is being reproduced. See further http://ec.europa.eu/yourvoice/ipm/forms/ dispatch?form=pandemicinfluenzan (last accessed 5 September 2011).

183 Taking European Knowledge Society Seriously, n. 77 above, p. 58.

184 M Leach and I Scoones, "Science and citizenship in a global context" in M Leach, I Scoones and B Wynne (eds), Science and Citizens: Globalization and the challenge of engagement (London: Zed Books 2005), p. 16.

185 S Walklate and G Mythen, “Agency, reflexivity and risk: cosmopolitan, neurotic or prudential citizen?” (2010) 61(1) British Journal of Sociology 45, p. 50.

186 Cf. Lentzos and Rose, "Governing insecurity”, n. 8 above, p. 235.

187 European Commission, "Pandemic Influenza Preparedness", n. 105 above, p. 9. 
As Jasanoff explains, generally the production of risk groups is an "effort to produce policy-relevant assessments" 188 of those thought to be differently and most affected by the threat in question and to attune governance to them and their needs. This might work to protect the vulnerable and interrupt a pandemic. ${ }^{189}$ One concern addressed shortly is how preparedness reshapes the value and use of risk groups. Another concern, discussed further below, is whether risk groups made subject to governance interventions have their human rights protected or in fact become, as an example, "at risk" of stigmatisation and excessive use of counter-measures. ${ }^{190}$ Here, I focus on the production of risk groups from supposedly neutral scientific knowledge. This works with moves towards selfmanagement and individualisation of responsibility to depoliticise and naturalise governance, and it reinforces the expert rationality underpinning preparedness and undermines democratic contestation. ${ }^{191}$

The latter is assisted by the re-emergence of the complementary public rationality through the use of physical and biological indicators to construct those at risk. Requiring further attention in relation to preparedness, Jasanoff notes how generally such "classifications tend to overlook the social foundations of vulnerability, and to subordinate individual experiences of risk to aggregate numerical calculations". ${ }^{192}$ The at-risk human is treated as a "passive agent"193 whose sociality and sources of vulnerability are masked. This increases the need for citizens to "regain their status as active subjects, rather than remain undifferentiated objects in yet another expert discourse". ${ }^{194}$

Turning to interventions, these fall within the essential infrastructure of prevention and containment. Vaccines and social distancing are central and are modulated throughout the alert levels. It is noted that "hand-washing and social distancing will play important roles in reducing the impact of pandemic influenza", ${ }^{195}$ vaccination is the key counter-measure, and since the production of vaccines usually takes between six and eight months, ${ }^{196}$ anti-virals are "the first pillar of medical prevention and intervention". ${ }^{197}$ While competence ensures the EU has limited involvement in health system response, the Commission and ECDC coordinate and review non-pharmaceutical measures. For instance, at Phase 5 this involves guidance on how "to optimize use of scarce facilities (triage, modified clinical guidelines, modified hospital infection guidelines .. .etc.)". ${ }^{198}$

To focus on vaccines, preparedness uses a variety of means, including support for research, ${ }^{199}$ a public-private partnership between public authorities and the vaccine industry to stimulate production, and an expedited market-authorisation procedure, all to deliver vaccine to the EU in the "shortest possible time". 200 Preparedness attempts to ensure equitable distribution of scarce resources and reduce vulnerability. For example,

188 Jasanoff, "Technologies of humility”, n. 10 above, p. 241.

189 Cf. J Upperman, "Vulnerable populations in disaster planning: children are different" in Katona et al. (eds), Global Biosecurity, n. 93 above.

190 Cf. Murphy and Whitty, "Is human rights prepared?”, n. 19 above, p. 237.

191 Jasanoff, "Technologies of humility”, n. 10 above, p. 241.

192 Ibid. (emphasis added).

193 Ibid.

194 Ibid. p. 241.

195 European Commission, "Pandemic Influenza Preparedness", n. 105 above, p. 12.

196 Ibid. p. 10.

197 Ibid. (emphasis added).

198 Ibid. p. 22.

199 See http://cordis.europa.eu/fp7/home_en.html (last accessed 5 September 2011).

200 European Commission, "Pandemic Influenza Preparedness", n. 105 above, p. 10. 
while again externalising the pandemic, the Commission helps to promote the "'mutualisation' of stocks to fight the disease at source" given "the lack of manufacturing capacity in many countries and the perceived imbalance between rich and powerful countries that collect strains through collaboration programmes with poor and affected ones but benefit from (their) manufacturers' production only themselves".201 Also, threaded through the alert phases is the responsibility of the Commission, ECDC and MS authorities to target - and improvise as they review and retarget in light of the unfolding pandemic - limited stocks of anti-virals and vaccines to key health personnel and the most vulnerable defined in risk groups. ${ }^{202}$

However, a key concern is the apparent focus of responsibility and skewing of attention and resources towards the protection of pharmaceuticals. This highlights the limitation of triage choices: pharmaceuticals are seemingly the means to deal with (and pre-selected by) the medical emergency model, but such that other, cheaper and perhaps more effective options are not so readily used. This is not necessarily to the advantage of risk groups since the normative direction of preparedness ensures pharmaceuticals are the focus of protection efforts - rather than those at risk. As such, preparedness reshapes the value and use of such classifications, essentially because they are aimed at mitigating adverse consequences to the economy and ensuring its optimisation, in part through resort to pharmaceuticals. In other words, it appears improvisation in triage choices is constrained, and the vulnerability of population increased, by the frame of medical emergency.

Added to this, even as wider preventive measures such as hygiene are governed by preparedness, the focus is still on protecting them, in order to optimise the economy, rather than protecting population. ${ }^{203}$ More widely, since the focus is on triage in medical emergency, broader public health interventions in population as part of a more concerted and long-term response are further undermined. Overall, the focus on pharmaceuticals implies the boundaries of responsibility and blame are effectively limited to failures in their protection as the preferred triage choice within the medical emergency model.

The prominence of pharmaceuticals has been explained by the close relations between the WHO and industry and the suggestion that the pandemic threat is talked up in order to generate orders. ${ }^{204}$ Some note that changes to the WHO's alert phases were prompted by, and privilege, industrial ties. ${ }^{205}$ This is pertinent to the EU given how its alert phases are aligned to the WHO's. Further, the clear bias of the EU's pharmaceutical regime is towards getting (high-cost) products to market, regardless of their comparative efficacy, in order to support and optimise an innovative economy. 206 This highlights the use and dissemination of market rationality in public health and open servicing of market needs as facilitated by preparedness and the wider exacerbating forces noted above.

201 European Commission, "Pandemic Influenza Preparedness", n. 105 above.

202 Ibid.

203 Staying at home and taking regular pain killers has been highlighted as the best option for most people infected with H1N1: Jenkins, "Swine flu?", n. 149 above. For discussion of triage choices in relation to humanitarian responses to emergency, see T Murphy, "Public health sans frontières: human rights NGOs and 'stewardship on a global scale"', this special issue.

204 D Cohen and P Carter, "WHO and the pandemic flu 'conspiracies"” (2010) British Medical Journal 340.

205 Such as when to declare a pandemic: ibid.

206 The emphasis is on quality, safety and efficacy rather than "comparative therapeutic efficacy" and genuine need: Hervey and McHale, Health Law and the European Union, n. 1 above, pp. 317-18. On the neoliberal orientation of EU pharmaceutical governance and biopolitics, see M Flear, "The EU's biopolitical governance of advanced therapy medicinal products" (2009) 16(1) Maastricht Journal of European and Comparative Law 113. 
Moving to social distancing, the ECDC must provide "scientific advice on nonpharmaceutical public health interventions", 207 and it works with the Commission and affected MSs, who must report on the effectiveness of their efforts through the EWRS in order to inform national and international planning. Social distancing becomes particularly important at Phase 6, when its use to regulate the internal market is highlighted. Indeed, the Commission must work with the MSs to:

coordinate ... the position on movement of persons and goods and cooperate with appropriate international organizations and associations and transportation companies to implement standard measures for travellers on board international conveyances, consistent with the alert level. ${ }^{208}$

Returning to the point introduced above, these are of special concern for risk groups who are produced as especially vulnerable and made subject to specific actions aimed at interrupting a pandemic, since it might make them vulnerable to repression. Medicine, law and governance work with metaphors of disease carriers to produce them as different from "normal" members of society. ${ }^{209}$ This production can work to provide the rationale for interventions, and they are highly susceptible to abuse. In other words, those deemed at risk of infection are also at risk of human rights infringements beyond the failure to ensure that they rather than pharmaceuticals are the focus of protection efforts. Wider exacerbating tendencies include the criminalisation of disease transmission, the wider securitisation of public health, ${ }^{210}$ and working with these, the figuration of disease carriers as active agents, aggressors and even "evil criminals" who must take responsibility for their condition and endangerment of others. ${ }^{211}$ Particularly vulnerable groups include those coming from outside the EU, the zone where the threat is deemed to arise, and typically itinerant and already marginalised groups within the EU, such as the Roma or travelling communities. ${ }^{212}$

Overall, as Murphy and Whitty stress, such interventions can "provoke or compound discrimination and stigmatisation of particular individuals and groups". ${ }^{213}$ Yet, as they go on to explain, the efficacy of such social distancing might also be undermined given that individuals might avoid diagnosis and treatment where quarantine seems a realistic possibility. ${ }^{214}$ In addition, such techniques and practices directly infringe personal liberty and privacy rights, and could lead to healthy individuals being put at serious risk of infection should they be mistakenly quarantined. Yet, since only certain risk groups are targeted for specific interventions, there is an absence of burdens on all. ${ }^{215}$ This combined with the individualisation and responsibilisation attendant to risk mean such actions could be further depoliticised and left largely uncontested.

207 European Commission, "Pandemic Influenza Preparedness", n. 105 above, p. 20 (emphasis added).

208 Ibid. p. 25.

209 Sontag, Illness as Metaphor, n. 160 above, p. 171.

210 S Elbe, "Pandemics on the radar screen: health security, infectious disease and the medicalisation of security" (2011) 59(4) Political Studies 848; S Elbe, Security and Global Health: Toward the medicalization of insecurity (Cambridge: Polity Press 2010).

211 J Montgomery, "Medicalizing crime - criminalizing health? The role of law" in C A Erin and S Ost (eds), The Criminal Justice System and Health Care (Oxford: OUP 2007). Cf. N Reis, "The 2003 SARS outbreak in Canada: legal and ethical lessons about the use of quarantine" in J Balint, S Philpott, R Baker and M Strosberg (eds), Ethics and Epidemics (Amsterdam: Elsevier Press 2006).

212 S Žižek, "Liberal multiculturalism masks an old barbarism with a human face", The Guardian, 3 October 2010. 213 Murphy and Whitty, "Is human rights prepared?", n. 19 above, at 235.

214 Ibid.

215 L Zedner, "Seeking security by eroding rights: the side-stepping of due process" in Goold and Lazarus (eds), Security and Human Rights, n. 153 above, p. 272, cited in Murphy and Whitty, n. 19 above, p. 235. Cf. M K Wynia, "Ethics and public health emergencies: restrictions on liberty" (2007) 7(2) American Journal of Bioethics 1. 
The wider linked forces traced above - greater security, the zero-sum relationship between human rights and risk (and safety and security), a focus on institutional risk and broader shifts towards reflexive governance, and the production of legitimacy - might reinforce the tendency towards (investment in 216 and) protection of pharmaceuticals and (admittedly currently to a lesser extent) social distancing. This is because, as indicated, in one way or another they seem to condition and reinforce a preference for the use of such interventions within a medical emergency model. ${ }^{217}$

To focus on legitimacy, the preference for pharmaceuticals might also be explained by their cultural resonance and use for legitimation purposes. That is, pharmaceuticals are now central to well-being and health, and are dominant in marketing strategies that favour selfmanagement and which are underpinned by the individualisation of risk. ${ }^{218}$ This makes pharmaceuticals useful for governance as a way of relating to and managing public expectations, and especially for setting and limiting the boundaries of responsibility and blame in the event of failure. The cultural resonance of pharmaceuticals helps to legitimate both the preference for them as a response to medical emergency and, through protection of their production and deployment, the preparedness regime.

This use of pharmaceuticals also undermines the political salience and use of other triage choices and broader public health interventions in population as part of a more concerted and long-term response. Put differently, it appears that a preference for pharmaceuticals (and constrained improvisation in triage choices) is politically useful as a way of relating to and managing public expectations in the face of what is constructed as a medical emergency in order to mitigate adverse consequences. However, this undermines resilience in that it also reinforces the distraction of attention away from, and use of responses that could deal with, the social conditions producing pandemics. Another aspect of legitimation is apparent in the EU's involvement in international pandemic planning to assist non-MSs as it seeks to govern its periphery and beyond. This helps to constitute the $\mathrm{EU}$ as an international actor, mark and secure its borders and identity, externalise the threat and limit the boundaries of its responsibility and accountability, and produce legitimacy by and through the demonstration of preparedness and response.219

Adding to these concerns, preparedness contains only background references to the legal and ethical implications of interventions. In the Interim Document, 220 the focus is more on ensuring minimal disruption to the internal market through assessment exercises and prior communication of counter-measures so as to ensure interoperability. ${ }^{221}$ For example,

216 Furedi highlights a twist: a "culture of fear" is used by those in authority and in the welfare and security industries to promote investment in security. See F Furedi, Culture of Fear Revisited 4th edn (London: Continuum 2006).

217 Cf. C Caduff, "Public prophylaxis: pandemic influenza, pharmaceutical prevention and participatory governance" (2010) 5(2) BioSocieties 199.

218 A Petryna and A Kleinman, "The pharmaceutical nexus" in A Petryna, A Lakoff and A Kleinman (eds), Global Pharmacenticals: Ethics, markets, practices (Durham: Duke UP 2006). Also see: S R Whyte, S Van der Geest and A Hardon, Social Lives of Medicines (Cambridge: CUP 2003), especially "Drug vendors and their market: the commodification of health". More generally, see G C Gray, "The responsibilisation strategy of health and safety: neo-liberalism and the reconfiguration of individual responsibility for risk" (2009) 49 British Journal of Criminology 326.

219 Furedi, Culture of Fear, n. 216 above.

220 For instance, "full respect for ethical standards, human rights, national and local laws and cultural sensitivities and traditions" in interventions is noted (European Commission, "Interim Document", n. 108 above, Annex 8, p. 78). It is supposedly a question of checking that "[n]ational plans include a leading ethical framework for responses to public health crisis and national plans include a verification processes to assure that the ethical aspects of policy decisions to be used during the response to an outbreak balance individual and population rights" (ibid. p. 35). The identity of the "leading" framework remains unclear.

221 As required for compliance with EU free movement law, see: Barnard, The Substantive Law of the EU, n. 80 above. 
"[e]thical issues are closely related to the legal issues ... and are part of the normative framework needed to assess the cultural acceptability of measures like quarantine or selective immunisation of pre-defined risk groups". 222 Of course, cultural acceptability is determined in part by the broader framing in governance and the forces sketched above. Even so, responsibility for the management of the ethical and legal implications of interventions including blame in the event of failure - is located at MS level.

Such a minimal concern for risk management highlights the EU's eschewal of responsibility for the distortions and failures in relation to interventions produced by, at least in part, its discourse on preparedness. This move also enhances depoliticisation and naturalisation of preparedness and helps to shield the EU from adverse public perceptions in the event of controversy and failure. Again, these perceptions are managed and contained by the boundaries of responsibility and accountability. These boundaries are communicated as being limited to the protection of essential infrastructures and especially the pharmaceutical response, but in order to mitigate consequences of a pandemic and optimise the economy.

Further, the public rationality of the deficit model re-emerges, this time in making the ethical and legal implications of interventions matters of expert discourse and deliberation at MS level. This also reflects a broader observation that the complementary expert and public rationalities are used to authorise and legitimate certain preparedness response strategies, such as through use of pharmaceuticals, and reinforce existing power relations towards the objective of economic optimisation. ${ }^{223}$

\section{Conclusion: towards learning, enhanced responsibility and resilience}

The analysis of preparedness highlights the operation of complementary expert and public rationalities in its constitutive discourses of risk, security, PUS, and which are undergirded by neoliberalism. While producing knowledge in an attempt to govern pandemics, the rationalities and discourses also delineate the boundaries of responsibility, and produce and mask governance distortions and failures. The rationalities also undermine participation because citizens are cast within a deficit model as being incapable of sharing in power to shape governance. In particular, citizens are limited through communication strategies to engage in hygiene efforts aimed at reducing contagion and pursuing their daily social and economic lives. Overall, the rationalities deny the normative within preparedness and essentially try to "mark off" governance from popular control and contestation.

In section 2, I nominated and made an initial sketch of supra-stewardship as a tool to resist the deficit model and facilitate citizen participation around framing, distribution and vulnerability in order to highlight the normative in the technical, especially the boundaries of EU responsibility, and the production of governance distortions and failures. In section 3, I suggested some of the contours for engagement by supra-stewardship to show how citizens might use it to become active subjects as they open up knowledge domains, contribute towards decision-making and expand EU responsibility and accountability to include the definition of the pandemic threat as a medical emergency and its attendant governance distortions and failures.

222 European Commission, "Interim Document", n. 108 above, p. 35 (and pp. 34 5 for legal implications). (emphasis added). For definitions, see Annex 3, pp. 64-6, available at http://ec.europa.eu/health/ph_threats/ Bioterrorisme/keydo_bio_01_en.pdf (last accessed 5 September 2011). On EU support for ethics in national plans, see in the workshop "Ethical issues in European national preparedness for pandemic influenza", www.eu2008.fr/webdav/site/PFUE/shared/import/1120_pandemie_de_grippe/Pandemie_grippe_Pandem ic_influenza_Programme_FR_EN.pdf (last accessed 5 September 2011).

223 Caduff, "Public prophylaxis", n. 217 above. 
Perhaps most important is using these insights to widen triage choices within the current frame of preparedness as being about dealing with a medical emergency and to guard against excessive and repressive measures. More difficult, given the limitations of that frame, is using the insights to inflect preparedness with a wider set of public health concerns in order to look beyond mitigating consequences and bolster interventions in the social conditions producing pandemics - and ensuring that pandemic governance is not to the detriment of wider public health objectives. Yet, in re-emphasising uncertainty, and although it requires further honing, supra-stewardship could highlight the need for a substantive input from those who are most affected by decision-making that cannot be based on the dominant hubristic technologies of risk and science alone.

Citizen participation and institutional learning could be fostered further by exploiting the rhetorical openings provided by the discourses constituting preparedness. For example, while used to construct the deficit model, PUS, especially as inflected through communication, could also be used to stimulate citizens' awareness, attitudes and preferences. Claims for violations of human rights and ethical obligations, especially in relation to broader public health objectives or societal risk, and built around framing, distribution and vulnerability, could exploit reflexive governance and the sensitisation of governance to the institutional risk of human rights linked to bioethics. This includes the potential for a human rights consciousness understood as being about empowerment to use bioethics in order to disrupt the interests and standing of the EU.224

A particularly useful platform could be the European Citizens' Initiative, "the first transnational instrument of participatory democracy in world history".225 Further reinforcement could come from moves towards organisational accountability and exploitation of the EU's legitimacy needs. Overall, the citizen input provided by suprastewardship could contribute towards better outputs and understanding of the limits of governance to organise uncertainty, helping to make preparedness and wider public health governance more secure and resilient in the event of failure.

224 Cf. "legal risk+" proposed by Murphy and Whitty, "Is human rights prepared?", n. 19 above, p. 233.

225 See www.citizens-initiative.eu/?page_id=2 (last accessed 5 September 2011). Established by Article 11(4) TEU and Article 24(1) TFEU. The practical arrangements and procedures are provided by Regulation 211/2011. Article 11(4) TEU provides "[n]ot less than one million citizens who are nationals of a significant number of Member States may take the initiative inviting the Commission, within the framework of its powers, to submit any appropriate proposal on matters where citizens consider that a legal act of the Union is required for the purpose of implementing the Treaties". This could produce a legal act under Article 168 TFEU. 
